\title{
EARLY CRETACEOUS EPI-PELAGIC SEDIMENTOGENESIS WITHIN THE EAST CARPATHIANS SEGMENT OF THE ANCIENT CONTINENTAL MARGIN OF THE MESO-TETHYS
} O. S. Shcherba, N. Y. Radkovets

\section{РАННЬОКРЕЙДОВИЙ ЕПІПЕЛАГІЧНИЙ СЕДИМЕНТОГЕНЕЗ У МЕЖАХ СХІДНОКАРПАТСЬКОГО СЕГМЕНТУ ДАВНЬОЇ КОНТИНЕНТАЛЬНОЇ ОКРАЇНИ ME30-TETICY}

\author{
О. С. Щерба, Н. Я. Радковець
}

On the base of geological-geophysical materials and lithological investigations of the rock samples of Lower Cretaceous deposits. For the first time geological map Lower Cretaceous level of the Outer zone of Carpathian Foredeep was constructed. The present distribution of the Lower Cretaceous platformian sediments of the Outer zone of Foredeep, was establish as a result the paleooceanogpaphical situation and sedimentogenesis conditions of these deposits within inner part of the paleoshelf of the East Carpathian segment of the ancient continental margin of the Meso-Tethys were revealed.

На підставі опрацювання геолого-геофізичних матеріалів та результатів літологічних досліджень зразків порід нижньокрейдових відкладів, вперше побудовано геологічну карту нижньокрейдової поверхні Зовнішньої зони Передкарпатського прогину. Встановлено сучасне поширення платформових нижньокрейдових відкладів Зовнішньої зони прогину, що дозволило з'ясувати палеоокеанографічну ситуацію та умови седиментогенезу цих утворень в межах внутрішньої частини палеошельфу Східнокарпатського сегмента давньої континентальної окраїни Мезо-Тетісу. Ключові слова: ранньокрейдова епоха, Східнокарпатський палеобасейн, седиментогенез, Мезо-Тетіс.

\section{ВСТУП}

Палеошельфові відклади ранньокрейдового віку в автохтоні Передкапатського прогину були розкриті багатьма свердловинами завдяки проведенню глибокого буріння, яке почалося в 50-х роках XX століття і продовжується до сьогодення. Це послужило поштовхом до стратиграфічного і літологічного вивчення цих нашарувань. Палеонтологічні дослідження, за результатами яких було зроблене розчленування нижньокрейдових відкладів (Лінецька, 1964; Дулуб, 1965), стосувалися лише північно-західної частини автохтона Передкарпатського прогину (свердловини Північні Мединичі-37, Вербіж-1, Угерсько-7) та прилеглої платформи (свердловини Підлуби-110, Язів-24, 85 та Яворів-49).

У 80-х роках XX століття, в межах Міжнародної програми геологічної кореляції (International geоlogical correlation programme, progekt No. 86 - South-west border of the East European platform), науковцями багатьох європейських країн проводились комплексні дослідження, які були присвячені глобальним геологічним подіям крейдового часу. Цими дослідженнями були охоплені крейдові відклади на значних територіях Західної та Східної Європи. Проте відклади, які знаходяться під насувною спорудою Карпат, не вивчалися.

Відкриття у Покутських Карпатах Лопушнянського родовища (1984р.) з покладами нафти і газу в автохтонних юрських, крейдових та палеогенових відкладах підвищило як науковий, так і практичний інтерес до нашарувань крейдового віку. На підставі проведених палеонтологічних досліджень у південносхідній частині автохтону Передкарпатського прогину (Гаврилишин, 1991,1998; Огороднік, 2005) для відкладів ранньокрейдового віку було встановлено окрім валанжину і готериву, баррем та апт. З'явилася низка праць присвячених літологічним дослідженням (Пастернак, 1980, 1987; О. Щерба, 1987; Радковець, 2002, 2004 та інші). Незважаючи на ці публікації, залишилося багато нез'ясованих питань.

Авторами, на підставі опрацювання геолого-геофізичних матеріалів значної кількості (більше 300) глибоких свердловин, а також результатів літологічних досліджень зразків порід, вперше побудовано геологічну карту нижньокрейдової поверхні Зовнішньої зони Передкарпатського прогину (рис. 1). На карті відображено сучасне поширення палеошельфових нижньокрейдових нашарувань в автохтоні Зовнішньої зони Східних Карпат, що стало вагомим підґрунтям для з'ясування умов седиментогенезу утворень ранньокрейдового віку. Як відомо, нижньокрейдові відклади, в межах дослідженої території, перекриваються сеноманськими нафтогазоносними нашаруваннями, тому такі дослідження мають не лише наукову цінність, але й практичне значення. 


\section{СХІДНОКАРПАТСЬКИЙ СЕГМЕНТ ДАВНЬОЇ КОНТИНЕНТАЛЬНОЇ ОКРАЇНИ ОКЕАНУ МЕЗО-ТЕТІС}

Карпатський палеобасейн у ранньокрейдову епоху займав північно-західну окраїну океану МезоТетіс. Дослідженнями була охоплена східна частина цього палеобасейну - Східнокарпатський сегмент, а саме континентальна окраїна - палеошельф (рис. 2). Палеошельф поділявся на дві частини внутрішню та зовнішню, умовно назвемо внутрішній і зовнішній палеошельф. Предметом літологічного вивчення були відклади внутрішнього палеошельфу Східнокарпатського сегмента Карпатського палеобасейну. Внутрішній палеошельф (глибиною 0-250 м) уособлював собою мілководну частину материкової обмілини, яка простягалася від берега до поглибленої частини морської водойми. Платформові відклади ранньокрейдового віку, які належали до зовнішнього палеошельфу Східнокарпатського сегмента не досліджувались, оскільки знаходяться під складчастою спорудою Карпат на значних глибинах 5,5 і більше км, що унеможливило отримання фактичного матеріалу.

Для Східнокарпатського сегмента Карпатського палеобасейну встановлено, що брівка палеошельфу в сучасній структурі регіону, орієнтовно, співпадає з зоною Закарпатського регіонального розлому (Сеньковський, В. Щерба, 1989 р.)

Умови осадонагромадження. Регресія, яка відбулася після юрського періоду зумовила виведення дослідженої території з-під рівня моря у беріаський час. Пізніше, внаслідок валанжинської трансгресії, у палеобасейні розпочалось осадонагромадження нижньокрейдових відкладів. Кліматичні умови ранньокрейдової епохи відзначалися високими температурами. Слід зазначити, що мезозойська ера, загалом, характеризувалася теплим кліматом, з відсутністю льодового покриву на полюсах. Окрім того район досліджень знаходився між $33^{\circ}$ і $36^{\circ}$ північної широти (Зоненшайн, 1987) і належав до субтропічного поясу, де середньодобові температури басейну седиментації ся-

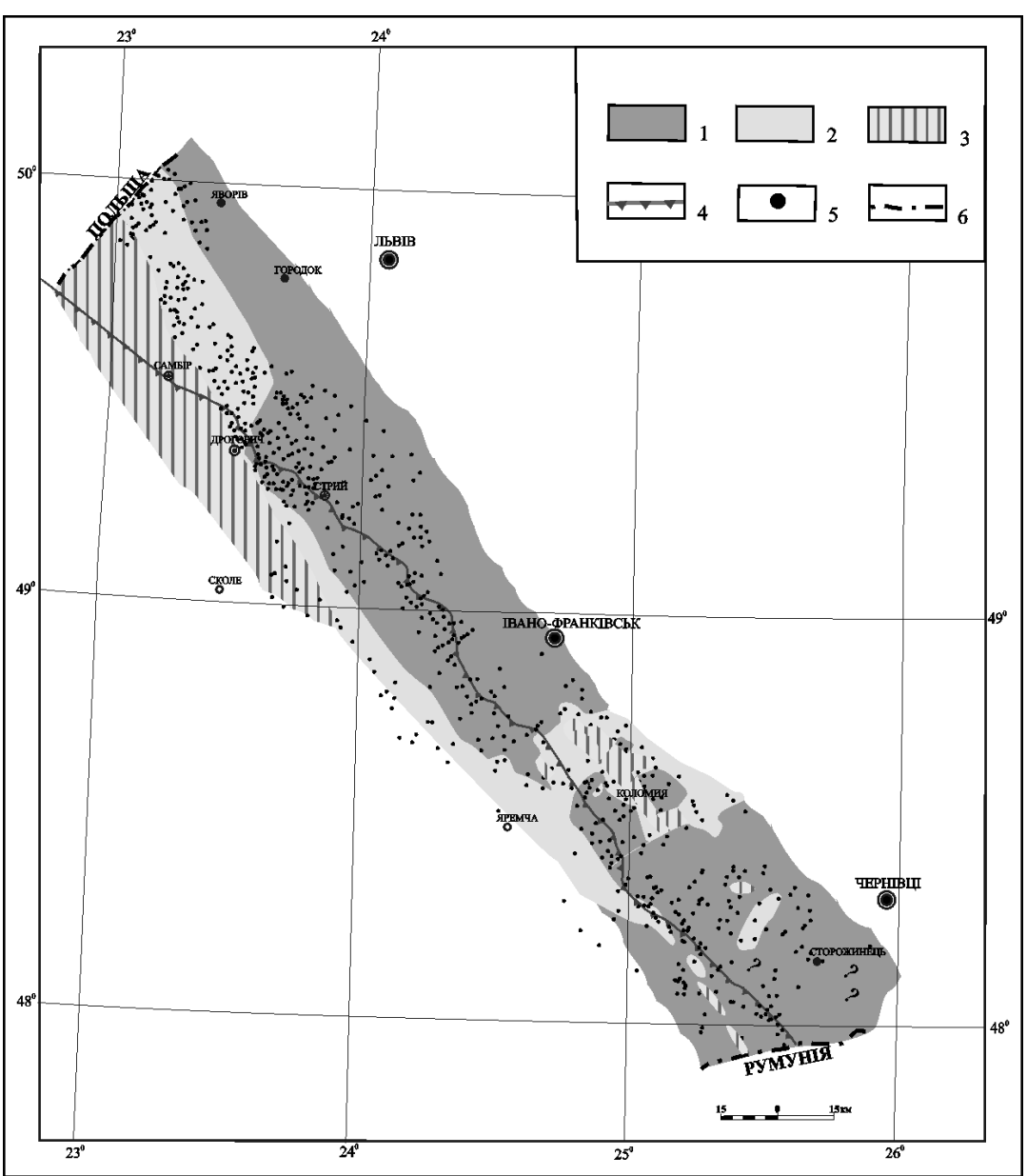

Рис. 1. Геологічна карта досеноманської поверхні автохтона Зовнішньої зони Східних Карпат. Склали: О. Щерба, Н. Радковець Відклади: 1 - нижньокрейдові, 2 - юрські, 3 - палеозойські; 4 лінія Стебницького насуву, 5 - свердловини, 6 - лінія державного кордону гали $+22^{\circ} \mathrm{C}$ (Вахрамеев, 1988). Глибини внутрішнього шельфу Східнокарпатського сегмента палеобасейну коливалися від перших метрів у прибережній частині до 250 м у напрямку континентального схилу.

На підставі літологічних досліджень для ранньокрейдових нашарувань встановлено три типи літофацій: карбонатна - у північно-західній, карбонатно-теригенна - у центральній, теригенна - у південно-східній частинах внутрішнього палеошельфу (Рис. 3). Типи літофацій відображені на перетині через розрізи свердловин: Північні Мединичі-2, Гринівка-11, (північно-західна частина), БогородчаниПарище-36 (центральна частина), Парище-14, Богородчани-Парище-54, Лопушна-4, Сторожинець-52 (південно-східна частина) (Рис. 4).

Нагромадження різних за літологічним складом нижньокрейдових утворень свідчить про відмінність умов седиментогенезу в цих частинах басейну та в межах прилеглої суші. Спробуємо з'ясувати причини неоднакових умов осадонагромадження. 


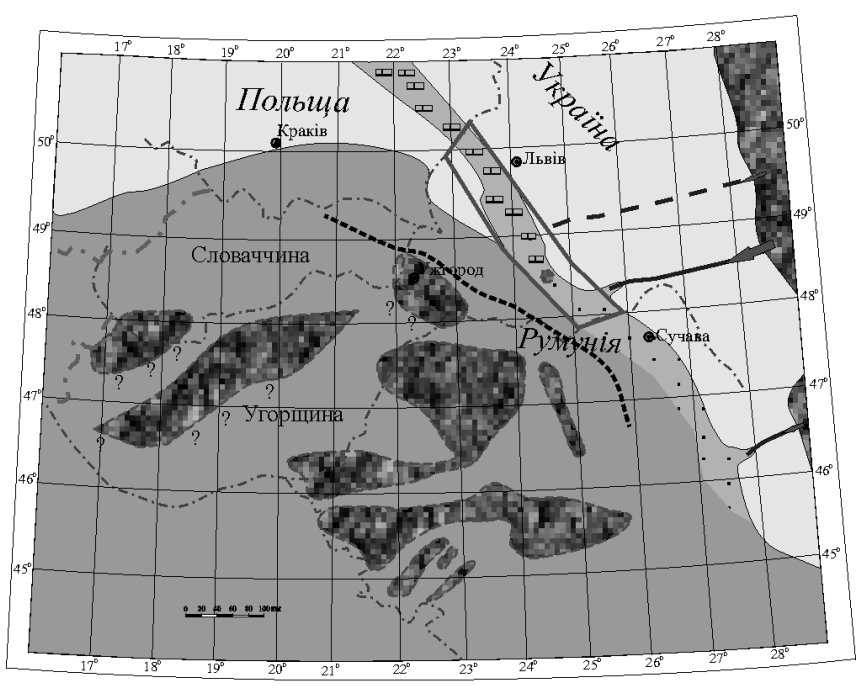

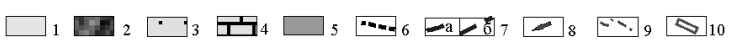

Рис. 2. Палеоокеанографічна карта-схема Карпатського сегмента Мезо-Тетісу (ранньокрейдова епоха). Складено за матеріалами (Atlas paleotransportu osadow...., 1976), з доповненнями Н. Радковець, О. Щерби.

1 - суша, 2 - область зносу теригенного матеріалу; відклади шельфу: 3 - карбонатні, 4 - карбонатнотеригенні, 5 - глинисто-теригенні; 6 - терени Карпатського сегмента океану Тетіс, 7 - палеорусло: а фактичне, б - ймовірне, 8 - напрямок зносу теригенного матеріалу, 9 - лінії кордону сучасних держав, 10 - район досліджень

Північно-західна частина внутрішнього палеошельфу була частково відмежована від Східнокарпатського сегмента басейну. Зв'язок з басейном перегороджувався Свентокшиською грядою. Це встановлено на підставі аналізу товщини нижньокрейдових нашарувань на межі зони Краковецького розлому, яка сягає 100-140 м, а за зоною розлому у напрямку континентального схилу поширені лише відклади юрського та палеозойського віку. В такій водоймі з достатньо високими температурами (не менше $+20^{\circ} \mathrm{C}$ ), були сприятливі умови для нагромадження карбонатної фауни: двостулкових молюсків, форамініфер, остракод. Надходження теригенного матеріалу як з боку берега (прилегла Західноєвропейська платформа), так і з Свентокшиської гряди було незначним.

Центральна частина внутрішнього палеошельфу теж була частково відмежована від Східнокарпатського сегменту басейну, але підводною грядою. У цій частині відбувалося не лише карбонатне, але й теригенне осадонагромаження. Теригенний матеріал, ймовірно, надходив з прилеглої суші по палеоруслу, про існування якого свідчить базальний конгломерат, встановлений С. Пастернаком (1980) у свердловині Журавно-14. Проте цей факт потребує ґрунтовніших досліджень.

Південно-східна частина внутрішнього палеошельфу характеризується глинисто-теригенним осадонагромадженням (глинисті пісковики, алевроліти, аргіліти). Винятком $€$ нижня частина товщі, де у розрізах встановлено незначної потужності (0-2 м) карбонатно-теригенні відклади (темно-сірі піщані вапняки з черепашковим детритом, вапнисті пісковики, мергелі). Таку седиментологічну ситуацію можна пояснити інтенсивним надходженням в басейн седиментації теригенноглинистого матеріалу з суші й острівної споруди (див. рис. 2) по палеоруслу, існування

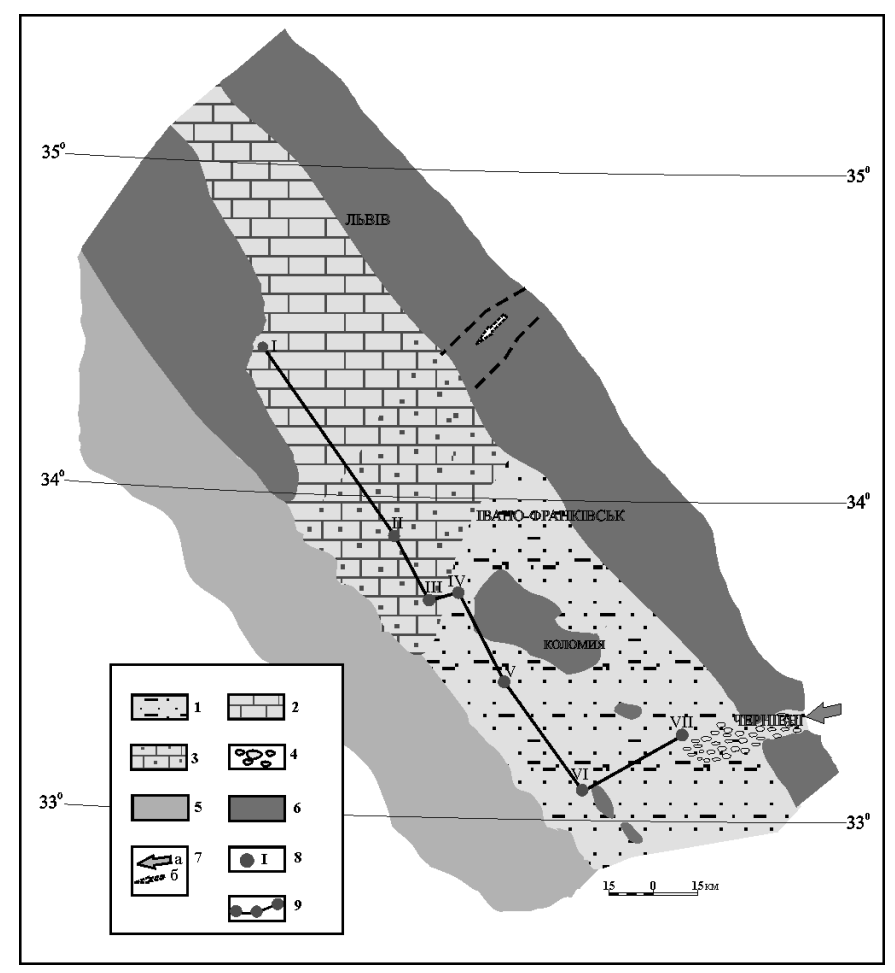

Рис. 3. Карта-схема поширення внутрішньошельфових утворень Східнокарпатського сегменту давньої континентальної окраїни Мезо-Тетісу. Ранньокрейдова епоха. Склали: Н. Радковець, О. Щерба.

1 - глинисто-теригенні осади, 2 - карбонатні осади, 3 - карбонатно-теригенні осади, 4 - грубоуламкові нашарування, 5 - недосліджені палеошельфові відклади, 6 - суша, 7 - напрямок скиду теригенного матеріалу: а - фактичний, б - ймовірний, 8 - свердловини, 9 - лінія кореляційного профілю 


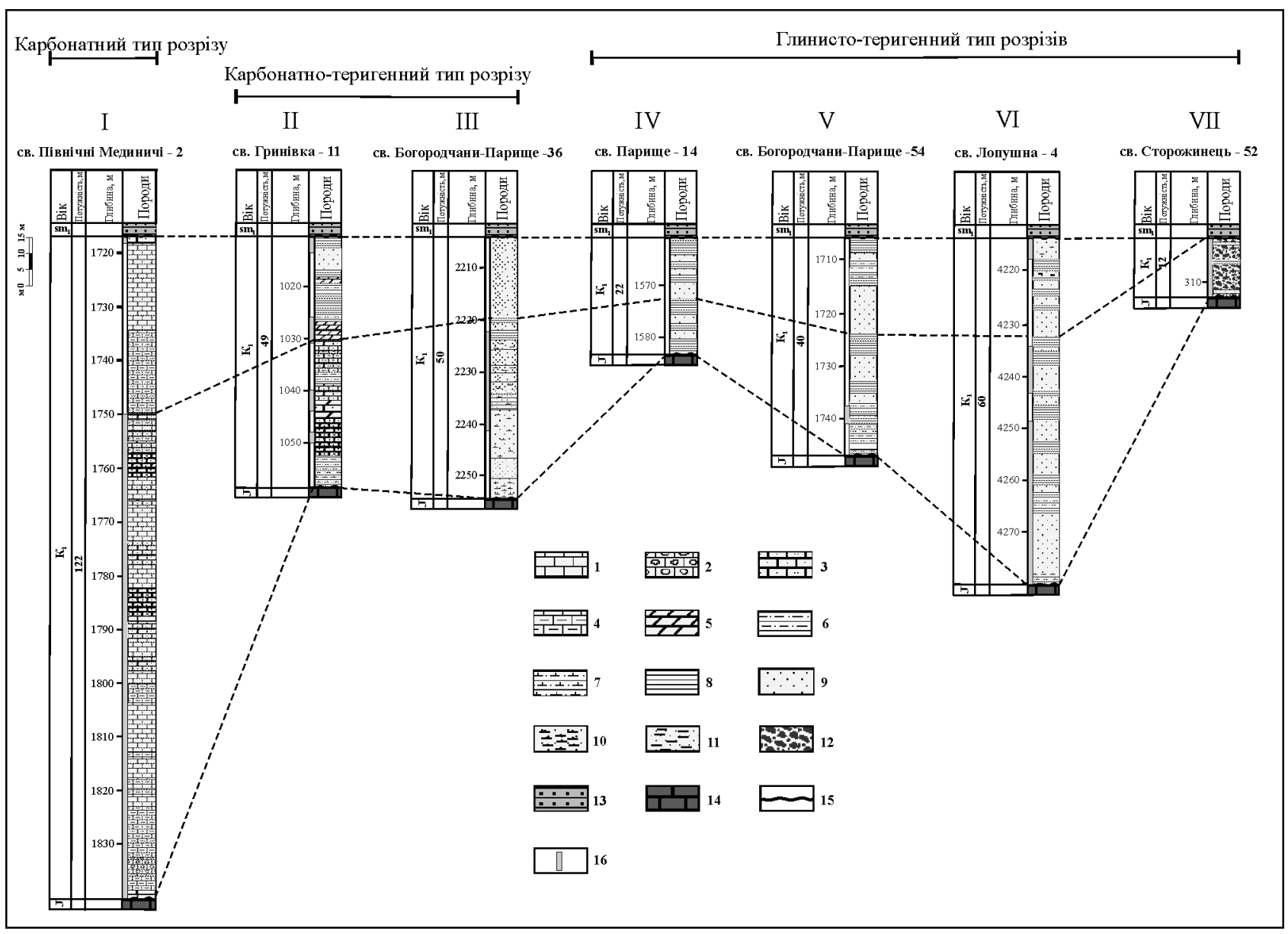

Рис. 4. Поздовжній кореляційний літологічний профіль через типові свердловини, які розкрили нижньокрейдові відклади в автохтоні Східних Карпат. Склали: О. Щерба, Н. Радковець.

Вапняки:1 - $з$ домішкою глинисто-теригенного матеріалу, 2 - псевдоолітові, 3 - піщані, 4 - глинисті; 5 - мергелі; алевроліти: 6 - глинисті, 7 - вапнисті; 8 - аргіліти; пісковики: 9 - кварцеві, 10 - вапнисті, 11 глинисті; 12 - гравеліти; відклади: 13 - нижньосеноманські, 14 - юрські; 15 - перерва в осадонагромадженні, 16 - інтервали відбору зразків порід кернового матеріалу, на яких проводились літолого-геохімічні дослідження

якого підтверджується наявністю у розрізах свердловин гравелітів, що зустрічаються на Східноєвропейській платформі (св. Сторожинець-52) (рис. 4) та прилеглій до неї частині Передкарпатського прогину (св. Сторожинець-39), а також гравіметричними дослідженнями (Біліченко, 1999). Потужність гравелітів на платформі становить 7-10 м, у прогині - 1-5 м, а у напрямку складчастої споруди Карпат поступово зменшується до нульових значень.

У пізньому баремі-апті (?) в межах внутрішнього шельфу Східнокарпатського сегменту палеобасейну внаслідок регресії, нагромадження нижньокрейдових відкладів припинилося. Досліджена територія була виведена з-під рівня моря і зазнала денудації.

Поширення палеошельфових відкладів. Палеошельфові відклади ранньокрейдового віку району досліджень у сучасній структурі залягають на розмитій поверхні юри і поширені на значній території Зовнішньої зони Передкарпатського прогину, а також частково охоплюють терени прилеглих Східноєвропейської та Західноєвропейської платформ (рис. 1). На деяких ділянках відклади ранньокрейдового віку відсутні і на поверхню виступають юрські та палеозойські утворення.

За результатами аналізу свердловинних геолого-геофізичних матеріалів встановлено, що палеошельфові нижньокрейдові відклади Зовнішньої зони Передкарпатського прогину залягають на глибинах 250-5517 м. а їх потужності зростають в напрямку занурення автохтона від перших метрів (на платформі) до 50-70 м (південно-східна частина прогину) і 140-150 м (північно-західна і центральна частини). 


\section{вИСНОВКИ}

1. Карпатський палеобасейн у ранньокрейдову епоху охоплював північно-західну окраїну океану Мезо-Тетіс. Дослідженнями була охоплена східна частина цього палеобасейну - Східнокарпатський сегмент, а саме континентальна окраїна - шельф (внутрішня частина) умовно внутрішній шельф, який простягався від берега до поглибленої частини морської водойми (0-250 м) - зовнішнього шельфу.

2. Район досліджень знаходився між $33^{\circ}$ і $36^{\circ}$ північної широти і належав до субтропічного поясу, де середньодобові температури басейну седиментації сягали $22^{\circ} \mathrm{C}$.

3. Для дослідженого району палеобасейну встановлено, що у північно-західній частині відбувалось карбонатне осадоногромадження, в центральній частині - карбонатно-теригенне, а в південносхідній - теригенно-глинисте.

4. Палеошельфові відклади ранньокрейдового віку дослідженої території залягають на розмитій поверхні юри і поширені на значній території Зовнішньої зони Передкарпатського прогину, а також частково охоплюють терени прилеглих Східноєвропейської й Західноєвропейської платформ.

5. На деяких ділянках дослідженої території відклади ранньокрейдового віку відсутні і на досеноманську поверхню виступають юрські та палеозойські відклади.

6. Максимальні потужності нижньокрейдових відкладів складають 50-70 м у південно-східній частині, 140-150 м - у північно-західній та центральній частинах прогину.

1. Біліченко В. Я. Структурно-тектонічні особливості праавтохтона Українських Карпат та прилеглих територій за матеріалами детальної гравіметрії // Геологія і геохімія горючих копалин. - 1999. - №3. - С.131- 138.

2. Гаврилишин В. И, Пастернак С. И., Розумейко С. В. Стратиграфическое подразделение меловых отложений платформенной части запада Украины /Препринт/ Львов: АН УССР Ин-т геологии и геохимии горючих ископаемых. - 1991. - 52 с.

3. Гаврилишин В. І. Стратиграфія платформових відкладів мезозою піднасуву Українських Карпат // Геологія і геохімія горючих копалин. - 1998. - № 3. - С. 81-90.

4. Вахрамеев В. А. Юрские и меловые флоры и климаты Земли. - М.: Наука, 1988. - Тр. ГИН АН СССР, вып. 430. $-214 \mathrm{c}$.

5. Дулуб В. Г. О нижнемеловом возрасте ставчанской свиты // Палеонтол. сб. - 1965. - Вып. 2, № 2. С. 113-115.

6. Зоненшайн Л. П., Деркур Ж., Кузьмин В. Г. и др. Эволюция Тетиса // История океана Тетис. - М.: Изд-во Ин-та океанологии АН СССР, 1987. - С. 104-115.

7. Лінецька Л. В., Утробін В. М. Про знахідки Tintinnidae, Cadosina, Stomosphaera i Globochete у мезозої Paдянських Карпат та Карпатського передового прогину // Доп. АН. УРСР. - 1965. - № 6. - С. 782-785.

8. Огороднік М. Є. Геохімічні та палінологічні аспекти дослідження відкладів нижньої крейди автохтона Покутсько-Буковинських Карпат // Геологія і геохімія горючих копалин. - 2005. - № 1. - С. 59-67.
9. Пастернак С. І., Сеньковский Ю. М., Гаврилишин В. І. Волино-Поділля у крейдовому періоді. - К. : Наук. думка, 1987. - 257 с.

10. Пастернак С. И., Улизло Б. М. Неоком Прикарпатья // Геология и геохимия горючих ископаемых. - 1980. вып. 55. - С. 22-30.

11. Радковець Н. Я., Сеньковський Ю. М. Седиментолого-палеоокеанографічні особливості формування крейдових відкладів Покутсько-Буковинського сегмента океану Тетіс (неоком, альб-сеноман) // Геологія і геохімія горючих копалин. - 2002. - №2. - С. 3-12.

12. Радковець Н. Я. До літологічного вивчення неокомнижньосеноманських відкладів автохтона ПокутськоБуковинських Карпат // Геологія і геохімія горючих копалин. - 2004. - № 4. - С. 10-19.

13. Сеньковский Ю. М., Щерба В. М. Проблема нефтегазоносности мезозой-кайнозойских отложений поднадвига Карпат и смежных территорий // Геологический журнал. - 1989. - № 4. - С. 36-41.

14. Щерба А. С. Литолого-фациальные особенности и коллекторские свойства нефтегазоносных отложений Внешней зоны Предкарпатского прогиба // Геология и геохимия горючих ископаемых. - 1987. Вып. 67. C. 33-39.

15. Atlas paletransportu osadow detrytycznych w luku Karpacko-Balkanskim. Czesc I - Tuton i kreda dolna 1 : 2000 000. - Redaktor naukowy Andrzej Slaczka. Warszawa: Instutut geologiczny, 1976.

Інститут геології і геохімії горючих копалин НАН України, м. Львів, Україна Institute of Geology end Geochemistry of Combustibles Minerals NAS Ukraine, Lviv, Ukraine 